\title{
Primary Physical Science for Student Teachers at Kindergarten and Primary School Levels: Part II-Implementation and Evaluation of a Course
}

\author{
Federico Corni $^{1}$ D Hans U. Fuchs ${ }^{1,2}$ (ID
}

Received: 1 June 2020 / Accepted: 2 February 2021 / Published online: 25 February 2021

(c) The Author(s) 2021

\begin{abstract}
This is the second of two papers on a novel physical science course for student teachers that develops and uses an imaginative approach to Primary Physical Science Education. General philosophical, cognitive, developmental, and scientific issues have been presented in the first paper; here, we briefly recapitulate the most important aspects. In the main part of the current paper, we present in some detail concrete elements of the implementation of the course at three Italian universities where Primary Physical Science Education has been taught for more than 6 years. After a brief description of the course structure, we discuss which parts of macroscopic physics are taught, and how this is done in lectures and labs. Most importantly, we show how the science is entwined with methods related to pedagogy and didactics that (1) help our students approach the science and (2) can be transferred quite readily to teaching children in kindergarten and primary school. These methods include the design of direct physical experience of forces of nature, embodied simulations, writing and telling of stories of forces of nature, and design and performance of Forces-of-Nature Theater plays. The paper continues with a brief description of feedback from former students who have been teaching for some time, and an in-depth analysis of the research and teaching done by one of the students for her master thesis. We conclude the paper by summarizing aspects of both the philosophy and the design of the course that we believe to be of particular value.
\end{abstract}

Keywords Primary physics education · Pre-service teachers · Embodiment · Metaphor $\cdot$ Narrative $\cdot$ Cognitive science

Federico Corni

federico.corni@unibz.it

$\triangle$ Hans U. Fuchs

hans.fuchs@narrativescience.org

1 Faculty of Education, Free University of Bozen-Bolzano, Via Ratisbona, 16, 39042 Bressanone, Italy

2 Institute of Applied Mathematics and Physics, Zurich University of Applied Sciences at Winterthur, 8401 Winterthur, Switzerland 


\section{An Imaginative Approach to Primary Physical Science Education (PPSE)}

In our first paper on the subject (Corni and Fuchs 2020: Primary Physical Science for Student Teachers at Kindergarten and Primary School Levels: Part I-Foundations of an Imaginative Approach to Physical Science-hereafter referred to as Paper I), we outlined our research program we call Primary Physical Science Education (PPSE). After summarizing the main points of Paper I in this introductory section, we shall discuss the structure, implementation, and evaluation of a physics course for Master Degree students in Primary Education, which follows the path laid out in the project. First, however, a few words concerning our main goals for the course and the purpose of this paper are in order.

\section{Course Goals and Purpose of the Paper}

In the course, we aim at empowering future teachers to become confident and competent creators and narrators of good stories of forces of nature ${ }^{1}$ for children in kindergarten and primary school, who know how to use these stories for creating narrative experience paralleling direct physical experience of forces of nature. We pursue this central goal through combining lectures and labs where we teach our students how to apply results of research on metaphoric and narrative structures in (physical) science to a description of macroscopic processes and systems that centers upon forces of nature such as wind, rain, light, and fire; heat, gravity, water and other fluids; thunderstorms and electricity; soil, plants, and food; and motion (see Paper I).

The physical science behind PPSE is derived from a generalized approach to dynamical systems in continuum physics. How formal physical science can be connected up with pedagogy suitable for kindergarten and primary school pupils has been the subject of research and development that has been described in Paper I. In this research, we have combined a critical review of epistemology and practice of macroscopic physics and its applications to natural and technical systems with enactive (embodied) cognitive science. Our central claim derived from that research is that direct physical experience of nature (by children) in parallel with narrative experience leads to abstractions and imaginative structures of mind that can be rediscovered in formal physical science, thereby forming a useful basis from which a later mature understanding of scientific and technical issues might arise.

Therefore, the purpose of this paper is to describe practical elements of pedagogy we have developed for PPSE that let future teachers imagine, learn about, and

\footnotetext{
1 We enlarge the scope of this goal to include forms of communication other than linguistic narratives, namely embodied simulations (such as when we use our bodies to represent what water and electricity "feel" and "do" in hydraulic and electric circuits, respectively; see Embodied simulations) and Forces-ofNature Theater plays where children can act as forces of nature in more complex systems (such as when food is produced through photosynthesis in leaves of a tree where different forces of nature interact and exchange energy; see sub-section Forces-of-Nature Theater).
} 
practice how they can create examples of narrative science didactics for children from about 3 to 11 years of age (the age range for kindergarten and primary school in Italy).

\section{Experience and Embodied Minds}

In designing an imaginative approach to primary physical science for student teachers we have been guided by the question of how children (and adults) experience nature, both directly, physically (see Dewey 1925), and indirectly through what has been called narrative experience (Caracciolo 2014).

Modern versions of the naturalistic approach to experience championed by Dewey are to be found in philosophy of mind and cognitive science under the headings of embodied cognition (Varela et al. 1991; Lakoff and Johnson 1999), aesthetics and phenomenology (Johnson 2007; Gallagher and Zahavi 2012), or (radical) enactivism (Hutto and Myin 2017; Di Paolo et al. 2018). We derive much of our sense of origin and meaning of concepts, models, and theories of physical science from what we know about the functioning of embodied minds.

An important part of the concept of imagination, which is so essential to our design of the science course, is related to the use of narratives in the form of stories of forces of nature (Fuchs 2015). Such stories provide a parallel avenue to the experience of nature. Caracciolo (2014), in particular, has outlined in detail how narrative experience is possible. Moreover, another source describing the fundamentally important role of narrative in human life is Gallagher's and Hutto's Narrative Practice Hypothesis (Gallagher and Hutto 2008) which demonstrates how children learn about other humans through hearing and reading stories. We believe the same is true for how understanding of nature can be nurtured through stories of forces of nature (Corni 2014).

\section{Forces of Nature ${ }^{2}$}

Many of the natural scientific elements of the course-the disciplinary contentsrevolve around the concept of Force of Nature. We use Force of Nature in the sense of a fuzzy category of phenomena that present themselves as agentive to the human mind. Phenomena that could be called primary forces of nature include wind, rain and water, fire an ice, heat and cold, (Sun-) light, thunder and lightning, food and fuels, and motion (see Table 1). In physical science, this list is streamlined and is made up of the typical headings of macroscopic physical theory: fluids, electricity and magnetism, heat, chemical processes, gravitation, and rotational and linear motion (mechanics) (see Table 2).

A specific force of nature is characterized by three main elements or aspects: quantity or extension, quality or intensity, and power. In the case of electricity, these are charge, electric potential, and electric power; in linear motion, they are (linear)

\footnotetext{
${ }^{2}$ See the section The Gestalt of Force of Nature in Paper I.
} 
Table 1 Primary (pre-scientific) forces of nature
Some primary forces of nature

Wind

Rain and water

Fire and ice, heat and cold

(Sun-) Light

Thunder and lightning

Food and fuels

Motion
Table 2 Formal list of forces of nature
Forces of nature in continuum physics

Fluids

Electricity and magnetism

Heat

Substances

Translational motion

Rotational motion

Gravitation

momentum, velocity, and mechanical power. (We construct the concept of energy from the primitive notion of power.)

Naturally, a concrete force of nature exhibits a rich web of special relations and properties that goes far beyond what we just summarized. Nevertheless, assuming that the idea of force of nature can be applied to the various agentive phenomena nature presents us with makes these phenomena similar to each other: our mind can make use of analogical reasoning to a high degree when dealing with physical science.

\section{Macroscopic Physics}

For the natural scientific basis for our course, we have chosen the generalized approach developed in continuum physics over the second half of the 20th century (Truesdell and Toupin 1960; Truesdell and Noll 1965) and, more specifically, in continuum thermodynamics (Müller 1985; Jou et al. 1996). A simplified and more easily accessible version of a generalized theory of macroscopic processes can be built by creating a theory of spatially homogeneous dynamical physical systems (Fuchs 2010 [1996])—see also Paper I: section on Identifying the Imaginative Structure of Continuum Physics.

Prominent features of this approach, which also forms the basis of physical aspects of engineering and systems science, earth and environmental science, and macroscopic phenomena in astrophysics, are the following (Fuchs 2010). A concrete 
theory contains fundamental or primitive quantities, laws of balance for fluidlike (extensive) quantities, constitutive relations, and the energy principle. The fundamental or primitive quantities used in a theory of continuum physics are those that derive from an analysis of the gestalt of Force of Nature applied to forces such as heat, electricity, substances, and motion. In the case of heat as a force of nature, these are hotness (thermal intensity), entropy (caloric: quantity of heat), and conductive flux of entropy; for all other phenomena, there are analogous intensive and extensive quantities including the conductive fluxes. ${ }^{3}$

\section{Narratology: Stories of Forces of Nature}

We have already referred to the importance of narrative for experience and an imaginative approach to PPSE (see also Paper I, sections on Stories of Forces of Nature: Narrative Framing of Natural Scenes; and Stories and Story-Worlds). Stories of forces of nature ${ }^{4}$ have played a central role both in science education of student teachers (they learn to analyze and use existing stories, and how to create their own in their teaching practice) and in classrooms and nature studies in kindergarten and primary school (Corni et al. 2014b).

\section{Cognitive linguistics: Image Schemas, Metaphor, and Analogy}

Cognitive linguistics (Geeraerts and Cuyckens 2010) has taught us how to look at the schematic action of mind and imaginative use of schemas in thought, particularly in metaphoric projection and analogical reasoning.

Schematism leads body and mind to the construction of force schemas (such as OBSTRUCTING or ENABLING; see Talmy 2000) and image schemas (such as SCALE, PATH, CONTAINER, IN-OUt, SUbSTANCE, DIFFERENCE, TENSION, FlOw; Johnson 1987; Hampe 2005; see also section Image Schemas in Paper I) that are used for giving embodied meaning to perception (such as seeing pressure structured as a VERTICAL SCALE, or heat as a (FLUID) SUBSTANCE capable of FLOWING into or out of bodies). Since schemas, which are perceptual units or gestalts, have internal structural logic (CONTAINER: INSIDE, OUTSIDE, BOUNDING SURFACE, allowing for IN-OUT passage of FLUIDS), their logic is applied in thought.

In the simplest case of metaphoric structuring of thought (Lakoff and Johnson 1980, 1999; see section Metaphor in Paper I), schemas are projected onto domains of knowledge (such as electricity or temperature) to form conceptual metaphoric structures (such as ELECTRICITY IS A FLUID SUBSTANCE or TEMPERATURE IS A VERTICAL SCALE). Concrete metaphoric expressions are witnesses to our imaginative forms of thought and understanding.

\footnotetext{
${ }^{3}$ See also Corni et al. (2018) for an outline of this structure applied to mechanical phenomena in the setting of Fisica in Moto, a laboratory for young learners created by Ducati Motor Company in Bologna, Italy.

${ }^{4}$ For examples of stories of forces of nature, see Fuchs (2011, 2013), Fuchs and Fuchs (2020), and below in section A student's research and master thesis in PPSE.
} 
It turns out that to a large degree, the exact same schemas are projected onto different forces of nature, rendering them similar to the human mind and allowing for analogical reasoning over the various fields of physical science (Fuchs 2010; Paper I: section Analogical Structures in the Descriptions of Forces of Nature, and Paper I: Fig. 2).

\section{Development of Cognitive Tools ${ }^{5}$}

When our students have to transform an approach such as the one described here, which makes use of elements of macroscopic physics, narratology, and cognitive linguistics, (from kindergarten through primary school) into concrete pedagogy for their young learners, they need to have an understanding of the development of mind and cognitive abilities of children as they grow and change. We have integrated the philosophy and practice of imagination in learning and the development of cognitive tools worked out by Kieran Egan $(1986,1997,2005)$ and coworkers. ${ }^{6}$

According to Egan, cognitive tools are tools that have been made available by cultures and are in some form "recapitulated" by the individuals growing up in such cultures. These tools are, in important ways, related to imagination and evolving forms of language use. For example, metaphor and narrative are cognitive tools that develop in, or are appropriated by, the minds of very young children going through a phase Egan calls mythic understanding, which is tied in with the phase of apprehension of oral language (Egan 1988; for an application of this perspective to physical science education, see Fuchs 2014). The second phase suggested by Egan and important for the education of slightly older children (going into adolescence) is romantic understanding. Cognitive tools that develop and play an important role in this phase are beginning literacy (and its eventual mastery, including list making, mapping, and diagramming), an appreciation of the power of perception, and a growing sense of external reality (including the developing ability of dealing with the overwhelming detail and richness of the external world).

\section{Structure of This Paper}

In the following sections, we shall describe concrete aspects of the implementation and teaching of PPSE to teacher students and their reactions to the course-always keeping in mind what this might mean for children learning about their encounters with nature and technical systems.

We first outline the structure of the course (section Structure of the course) that has been taught over the last 6 years at three universities. Note that a description of philosophic and cognitive issues is left out-we refer here to Paper I and the short summary above.

\footnotetext{
5 See the section Cognitive Tools: Tools of Imagination in Paper I.

${ }^{6}$ See the resources made available at http://www.circesfu.ca.
} 
In section Themes treated in the course, we show how we introduce student teachers to primary forces of nature such as wind, rain, fire, light, heat and cold, food and fuels (see Tables 1 and 2); this forms a precursor to a more rigorous treatment of forces of nature in macroscopic physical science, a theme we will touch upon at the end of the section where we show how system dynamics models of natural and technical systems can be created and made use of by our students. Primary forces of nature are a subject that lends itself quite easily to direct transfer to classrooms and outdoor learning environments ${ }^{7}$ for the youngest learners in kindergarten and the first couple of years of primary school.

We then move on to describe how embodied simulations and Forces-of-Nature theater can be created (where we suggest to our students how our bodies can be used to express knowledge and understanding of physical systems and act out stories of forces of nature); simulations and plays can be applied to cases of physical and technical systems interesting for later years in primary school as well. Importantly, Forces-of-Nature theater makes use of a metaphorical and narrative approach to the role of energy in physical systems and processes.

This section continues with a couple of short subsections on how to analyze, create, and use stories of forces of nature, and how we let students apply their knowledge in a laboratory project where they analyze the processes taking place in a toy and create a story and a Forces-of-Nature Theater play for the system they analyze.

In concluding this long section, we describe how we introduce students to system dynamics modeling and simulation of simple physical and technical systems. System dynamics modeling supports our students' understanding of properties and roles of forces of nature in natural and technical systems, and it can be used, particularly in conjunction with embodied simulations, with older children in primary school.

In section Steps Towards an Evaluation of the Course, in order to evidence our students' reaction to the course, we present data from some relevant items in the end-of-course survey. Moreover, to show how student teachers make concrete use of the education they received in our PPSE courses, we report results from a questionnaire collected from former students who are now practicing teaching. And finally, in a little more depth, we present a case study of the research and teaching internship of a student at the end of her Master-Degree course.

In Summary and Conclusion, we briefly summarize what we believe are the most important results of our implementation, teaching, and evaluation of the PPSE course.

\footnotetext{
${ }^{7}$ While this is not the main direction of research and development in PPSE, our approach uses aspects known from Land Based Education (see, for instance, https://knowingtheland.edublogs.org/land-based -education-program/). We refer to the aspect of stressing direct (physical) experience of forces of nature. Moreover, we find good examples of stories of forces of nature in aboriginal myths; importantly, this relates to Egan's $(1988,1997)$ educational philosophy which we make use of when we develop the theme of cognitive tools of mythic culture (see above and Paper I).
} 
Table 3 Course contents and time allotted to subjects (referring to the lectures)

Lecture topic

$\%$ of time

devoted to

subject

1. Philosophical foundation

3

2. Linguistic tools: image schemas and metaphors

3. The gestalt of Force of Nature

4. Extensive and intensive physical quantities and constitutive relations

5. Analogical treatment of forces of nature

6. Energy

7. Cognitive tools in mythic and romantic understanding

8 . How to build a story

\section{Structure of the Course}

Over the last 6 years, the theoretical foundations outlined in Paper I and summarized in the introduction (An Imaginative Approach to Primary Physical Science Education) have been used to develop a physics course for student teachers for kindergarten and primary school levels that integrates lectures, laboratory, and, for some students, teaching apprenticeship and thesis work revolving around physical science.

At Italian universities, the physics course in the Master-Degree Program in Primary Education provides 8 credits for lectures, plus 1 credit for laboratory activities. It is taught either in the third or the fourth year of the 5-year course of studies.

The specific course we are going to present has been taught 12 times in the last 6 years at three different Italian universities with slight differences in the laboratory part. It has been taught at the University of Modena and Reggio Emilia (third year, from academic year 2013-14 to 2018-19), at the University of Verona (third year, in 2014-15), and at the Free University of Bozen-Bolzano (third and fourth years, starting in 2014-15) where it is still being taught and further developed. Depending upon the university, the hours for lectures vary from 56 to 60 , and those for the laboratory from 16 to 25 . The number of students in a single year range from 80 to 120 .

Since conditions and structures vary to some degree from university to university, we shall describe some of most typical concrete examples of our approach to lectures and labs. It is possible that the description of a particular example or case will not apply in detail to a course taught at the different sites; rather, it is meant to give the reader background information on how central elements of such a course can be implemented.

\section{Course Topics}

Table 3 lists the contents of the course by broad categories with the corresponding percentage of assigned hours in the lecture part of the course. The topics covered 
mirror the model for PPSE described in Paper I and synthesized briefly in the introduction (An Imaginative Approach to Primary Physical Science Education).

\section{Lectures}

Lectures are offered in a lecture hall suitable for demonstration experiments and for some embodied simulations (role playing of physical processes by groups of students). Attendance is not mandatory: the average number of students attending lectures is about $60 \%$ of those taking the course. Factors that affect attendance are the large number of working students (varying over the years from 20 to $40 \%$ of the enrolled students), and the fact that some students may be occupied with exams and with teaching apprenticeships. A Moodle module is available for sharing materials with students and for communication. Students are requested to write a summary of one of the lectures; they do this in teams for a particular lecture assigned to them (this is part of the exam requirements, see below).

\section{Laboratory}

Laboratory activities are designed as periods of practical activities where students have an opportunity to apply some of the contents covered during lectures with a focus upon primary education. Attendance is compulsory for students to be admitted to the final exam. Laboratories are organized in workshops of 25 to 35 students working in teams of 3 to 5 persons. They take place after most or all of the lectures are over with. The activities vary from university to university depending upon particularities of the curriculum. Activities may be one or more of the following: small experiments dealing with dynamical physical systems; working on a project investigating a toy; learning to analyze and write stories of forces of nature; and creating and acting out plays of forces of nature (which we call Forces-of-Nature Theater). ${ }^{8}$ In sub-section Toys and forces of nature-A lab project, we describe the most frequently and recently adopted structure of laboratory activities. In general, student teachers are invited to put themselves into the frame of mind of children and test their skills in applying what they have learned from the lectures. After the laboratory work, students should have directly experienced the various aspect of designing and constructing didactic activities according to the imaginative approach taught in the course.

\footnotetext{
${ }_{8}$ Previously, we called this Energy Play (Corni et al. 2019b; Landini et al. 2019). In order to avoid confusing our approach based upon fundamental aspects of forces of nature with Energy Theater (Close and Scherr 2015), we use the term Forces-of-Nature Theater. Energy Theater only represents properties of energy without regard to underlying physical systems and processes. In Forces-of-Nature Theater, the main "players" are agents representing forces of nature rather than energy. Energy is carried by these agents and plays a subsidiary, if important, role (see section Forces-of-Nature Theater).
} 


\section{Final Exam}

There is a final course exam covering lectures and labs. Part of it is taken in teams (usually the lab teams), part has to be performed individually. Teams prepare certain materials for this exam: (i) an extended summary of a single lecture assigned to them, (ii) a process diagram of processes taking place in a toy which they have studied in the lab, and (iii) a story about forces of nature for children at an age of their choosing from 3 to 11 years old. The examination consists of a group discussion based upon the materials they bring with them, and of questions about the course contents that have to be answered by the students individually.

\section{Remarks Concerning the Subsequent Discussion of the PPSE Course}

Most of the course contents covered during lectures, particularly those referring to items 1-3 and 7 in Table 3, and the general aspects of an imaginative approach to physical science, have been presented in some depth in Paper I; they have been summarized briefly in the section An Imaginative Approach to Primary Physical Science above. For this reason, we shall now concentrate upon special topics in physical science and their implementation in lectures, plus some practical elements dealt with in the laboratory. Note that certain aspects of the implementation of our course-such as the division of labor between lectures and labs-depend upon the university and which academic year our students are in. Therefore, what we discuss here should be taken as exemplary for how a course might be structured.

\section{Themes Treated in the Course}

In the following, we will describe mostly those elements of our course that suggest how practical examples of PPSE can be created that are suitable for children both at the younger and the older ends of the age range spanning kindergarten and primary school.

\section{Primary Forces of Nature and Forces in Formal Physical Science}

After philosophical and linguistic subjects have been covered during early lectures, we begin with physical science topics in our course. The first encounter with forces of nature is given a pre-scientific and purely qualitative and pictorial/visual form. We call upon a list of primary forces the awareness of which we shape in our direct experience of physical nature (Table 1). Later, we point out that categorization of forces of nature in (continuum) physics takes a different form (Table 2).

Primary forces of nature afford a treatment of natural phenomena accessible to young minds. How they can be conceptualized and dealt with in imaginative uses of language is therefore quite important to our student teachers. The transition from 
pre-scientific to scientific forms of conceptualization occupies a fairly large part of the course.

It is here where we introduce examples of stories of forces of nature (commonly in a form useful for children) such the Winter Story where COLD as a force of nature is the main character (Fuchs 2011). One type of story that has proved quite useful are nature myths of aboriginal peoples. An example we have been using more and more frequently is Why we need wind (also called Gluscabi and the Wind Eagle), ${ }^{9}$ which has apparently been used widely by a large number of North American native peoples. The story tells how the young hero, annoyed by being constantly interrupted from fishing by strong winds, goes to the mountains to make the wind eagle Wuchowsen stop producing wind-which backfires since the air will become bad and foul smelling in the valley. The hero climbs back, releases the eagle and reaches an agreement that, from now on, the wind will blow only during some periods. ${ }^{10}$

Both in the Winter Story and in Why we need wind, we learn about the properties of characters such as cold or wind. Their basic properties are the same as those that will be identified as formal concepts in physical science: intensity, amount or size (extension), and power (which, in scientific form, is related to the concept of energy).

When it is time to move gently toward a scientific treatment of forces of nature, we use conceptual structures as they are constructed in continuum physics. For reasons of brevity and to give priority to the description of the innovative features of the course that suggest how ideas native to PPSE can lead to concrete pedagogy for kindergarten and primary school, we refer the reader to Paper I: Identifying the Imaginative Structure of Continuum Physics.

\section{Embodied Simulations}

We want our students to understand physical science aspects tied in with bodily experience, everyday language, and conceptualizations accessible to the mind of a child. How this is achieved in a lecture or laboratory will depend upon aspects of infrastructure and time available. However, given the importance of this aspect for student teachers, we want to describe examples of embodied simulations of physical processes and constitutive relations that may even be played out in a lecture.

\footnotetext{
${ }^{9}$ One of the sources for this story can be found at http://www.angelfire.com/ia2/stories3/wind.html. The word Wuchowsen, which is used in the original native languages for the wind eagle, is actually not a name but a verb or adjective meaning blowing (making wind) or it-is-windy (Leavitt 2011). This reminds us of an important issue relating to primary understanding. We experience wind, not air, and we experience rain, not water, in some of the primary encounters with nature. Therefore, teachers of small children need to be cautioned about how to guide their students toward experiences of nature. Air and water, as substances or, rather, matter, are concepts that form only later in the life of a student-they are related to a more modern stage of literate culture (Egan 1997)—and should be distinguished from primary experience of forces (Fuchs and Cervi 2015).

${ }^{10}$ Notice the occurrence of feedback in this story-this is an example that can be useful for early encounters with systems thinking.
} 

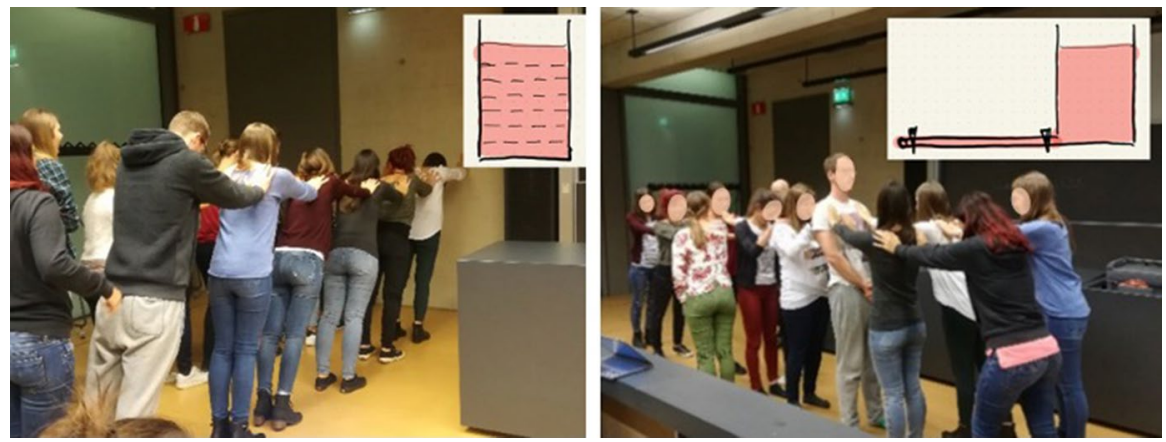

Fig. 1 Students experiencing the analogue of hydraulic stress of water in a bottle, increasing with depth (left), and simulating water in a bottle and a pipe leading out of the bottle (right: students on the right are in the bottle, those on the left are in the pipe). The student in the middle facing right simulates a closed valve

Imagine you have enough space in a lecture hall to call upon a number of students to act out simulations of certain situations-for their own benefit as well as that of their fellow students watching them. We are referring here to balance of amounts of fluidlike substances, expressions of tensions, resistive processes, capacitive relations, the working of pumps or generators, and the application to small dynamical elements. ${ }^{11}$ Further below in Forces-of-Nature Theater, we shall describe how processes in larger systems where several forces of nature interact can be represented as theatrical plays.

\section{Balance of Amounts of a Fluidlike Quantity}

We can give students an opportunity for developing an embodied sense for laws of balance of fluidlike quantities such as electric charge, caloric (entropy), momentum, and volume of fluid. Naturally, what we are going to describe here can, and maybe should, be applied to other quantities such as money or number of people in a city as well. $^{12}$

All we need is enough space for marking off an area of the floor as a storage unit for the fluidlike quantity we would want to work with. We need enough students to represent this quantity, and we need a number of observers, controllers, and "timekeepers" who write down the number of students in the storage unit in the course of time, magnitude of flows (and possibly production rates), and time period, respectively. Time is divided into periods (time steps or "rounds") during the simulation.

\footnotetext{
11 Because of their central importance for metaphoric conceptualization, we use simple hydraulic systems. If we allow for analogic transfer, the situations can be understood as embodied simulations of other phenomena-such as electrical or thermal—as well.

12 This game has been described and made available in the context of the System Dynamics in Education Project at MIT in Cambridge, MA. See Creative Learning Exchange: The Shape of Change. http:// www.clexchange.org/cleproducts/shapeofchange_lessons.asp.
} 
A timekeeper calls out the numbers of consecutive periods $(1,2,3, \ldots)$. During a round of the game, a number of students enter, and a usually different number of students leave the storage unit. These numbers are defined beforehand by the controllers, and observers keep track of relevant numbers as time steps follow one another.

Flows, production rates, and initial number of students in the storage unit are varied, and results are later analyzed. Part of the analysis requires students to compute the rate of change of number of students in the storage unit. The main learning that should take place is this: all flows and production rates added up (with proper signs) tell us how fast the stored quantity is changing.

\section{Collecting Water in an Open Tank}

It is fairly simple to simulate an experience of what happens to water collecting in a tank. We need a few students and a wall (see Fig. 1, left). A single student will represent a layer of water. Adding a first layer of water to an empty tank is simulated by a first student leaning against the wall-representing the bottom of the tankwith outstretched arms. The student is asked to observe what he or she experiences: there should be a feeling of mechanical stress of a certain magnitude in the body, an equally in the arms. When a second student representing the next layer of water leans against the shoulders of the first, this student should feel (about) the same stress in body and arms. For the first students, however, the situation has changed: the stress in his/her arms should have doubled. Subsequently, more students join a lengthening queue: in this manner, a certain number of layers of water in a tank is simulated.

Note that the feeling of (magnitude of) stress in body and arms represents the hydraulic/mechanical situation of the water quite faithfully. The stress in the bodywhich should be equal for every student in the queue-simulates the weight of a layer of water. The growing stress in the arms, on the other hand, simulates the rising pressure of the water; interpreted from the viewpoint of mechanics, this is the rising force (per cross section) on the water layers as we proceed downward to the bottom of the tank.

Water in a wider tank can be simulated by creating two parallel queues. This allows us to understand the fact that the pressure of the water rises only with depth and is independent of the cross section of the tank or the actual amount of water.

\section{Resistive Flow}

Simulating resistive flow of water through a pipe can remind us of forms of embodied understanding that are well known in everyday life. We all understand the bodily feeling of resistance or the raising of obstacles or impediments to motion which we force ourselves to perform-which is transferred as a matter of fact to non-literal, i.e., metaphoric, situations such as resistance to some form of effort, social or emotional or otherwise.

We can bring embodied experience of resistive transports to the classroom by asking two groups of students to form two chains facing each other that will represent the facing walls of a pipe. A third group of students will act as water "flowing" 


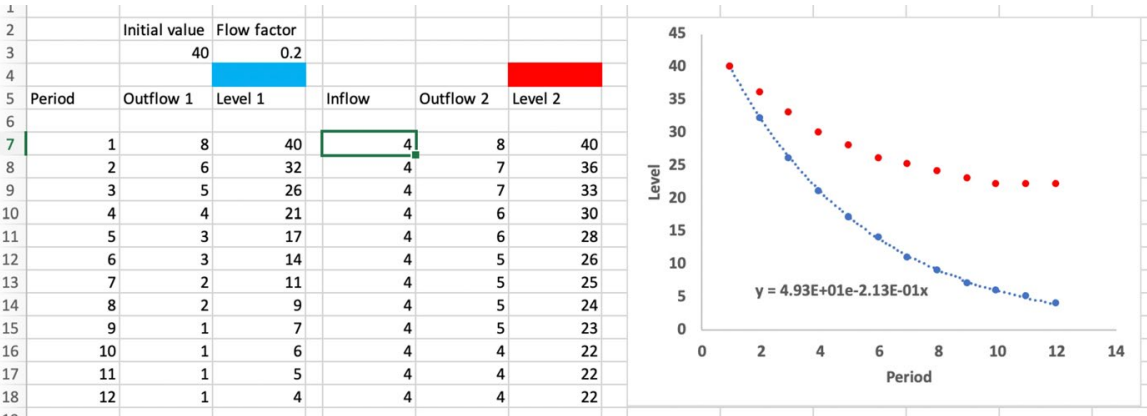

Fig. 2 An example of two simulations of "discharging of a water tank" with integer numbers of students (blue dots). The red result is for when we have an additional constant inflow. The "flow factor" is used to determine the fraction of students leaving the tank per unit time, based upon the "level" (or density) of students in the circle (which has been taken to be equal to the number of students in the circle). (Color figure online)

through the conduit between the walls, and an additional small number of students plays a pump that will force the "water students" through the conduit. The situation allows for changes of the effort of the students playing the pump, and the width and length of the conduit. Students can then observe the resulting "current of water" as a function of effort and magnitude of impediments to this flow.

If the students embodying the water in the pipe form a chain with outstretched arms on the shoulders of the person in front of them and do not resist with their lags, they should be able to notice that the stress in their arms is largest for the person nearest to the "pump" and lowest (basically equal to zero) for the person just exiting the conduit. If there is a valve at the end of the pipe, and water does not flow, we should notice that the stress in the arms is the same for every student simulating water in the pipe.

\section{Tank, Pipe, and Valves}

If the previous two examples have been successful, it is fairly easy to combine the situations (water in a tank and water flowing through a horizontal pipe fitted to the bottom of the tank) and add students playing the function of valves that can be opened or closed (see Fig. 1, right).

\section{Simulation of Discharging of a Tank Through a Horizontal Pipe}

Consider again a small system with water in a tank flowing out through a horizontal pipe at the bottom. Here, the physical situation to be simulated is simplified so that students can concentrate on the temporal behavior of the level of water, i.e., the capacitive pressure difference across the tank.

A large circle on the floor represents the tank. It is "filled" with as many students as can possibly fit in there. The pressure of the water in the tank is felt as a function of "density" of students in the circle, and the magnitude of this pressure is taken as 

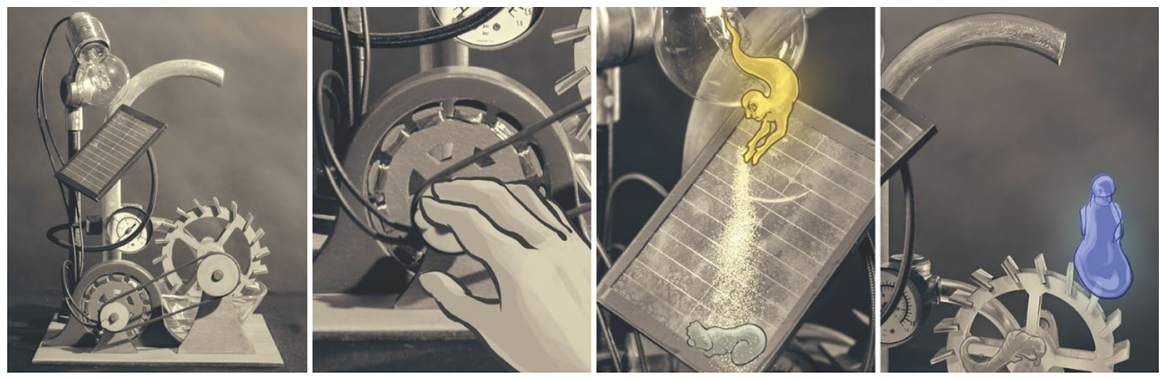

Fig. 3 The inventor's perpetual motion machine (left). Initial push (2nd from left), after which forces of nature appear in the shape of spirits

a measure of how badly students want to get out of the space marked by the circle. The situation-specifically, the number or density of students-is monitored by an observer. Another observer "measures time" and indicates when a period of time has elapsed (as in the first example of simulating the balance of amounts described above). During a single period, a number of students proportional to the density of students in the circle is asked to leave the circle. (Naturally, it will be difficult to do this in a precise manner with integer numbers of persons!) The result will be an exponentially decaying density or tension in the tank (Fig. 2, blue dots).

The situation allows for an interesting variation: we can let a fixed number of students "flow" into the tank per unit period of time and observe the temporal behavior of the system under these conditions (Fig. 2, red dots).

\section{Introducing the Energy Principle}

So far, we have not used the energy principle in our teaching and discussions of physical systems and processes with student teachers. The fact that we did not need to do this is one of the important aspects of learning about forces of nature: as long as there is basically a single force to be considered in a model, energy relations are not needed for understanding!

As we shall now see, the need for an energy principle arises primarily ${ }^{13}$ from the need for describing interactions of forces. When we introduce the energy concept in our course, we do so with the help of an animated story (Deichmann 2014) that provides an imaginative approach to forces of nature and their relation to energy (see also Corni et al. 2019b).

\footnotetext{
13 We deliberately write "primarily." There are cases and applications where we want to calculate energy quantities even if this is not necessary for a model of a dynamical physical system. Such situations arise mainly in energy engineering and predominantly in energy economics where we focus, almost exclusively, on accounting for energy quantities.
} 

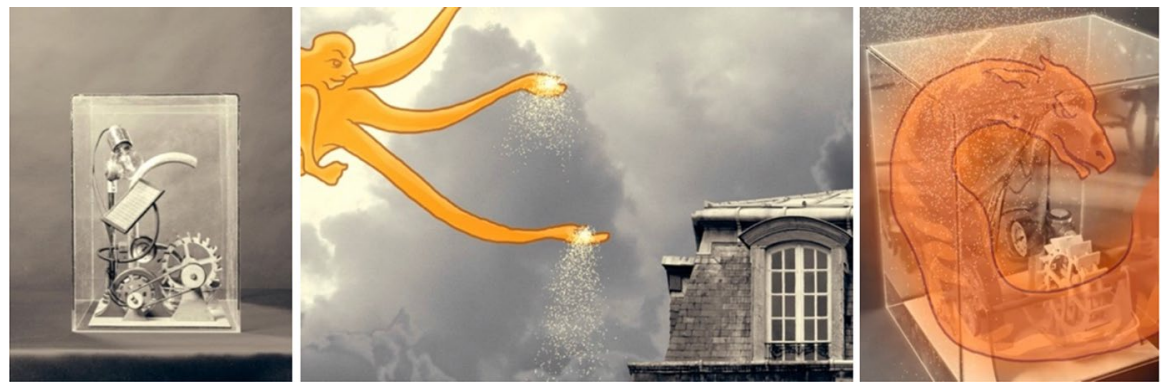

Fig. 4 Put under a glass cover, the machine is tucked away in the attic of a museum. Luckily, its solar cell faces the window. When the sun shines through the windows into the room, the machine starts running. Heat is produced in the engine which breaks the glass cover and finally sets the machine free

\section{Perpetuum Mobile-An Animated Story of Forces of Nature}

The animation tells the story of an inventor who dreams of the perfect perpetual motion engine (Fig. 3, left). When he finally builds it, it seems to work at first.

He starts the generator by hand, turning its axle (Fig. 3, second from left). This makes the electricity flow which, in turn, lights the lamp. The light of the lamp drives the solar cell (Fig. 3, second from right) which drives a water pump. The water is pumped high, falls down upon the water wheel (Fig. 3, right) which now turns and drives the generator, and so on, ad infinitum or in perpetuity...

However, since every operation produces some heat, the energy made available by the inventor during the initial "push" and then "handed" from part to part inside the machine, becomes less and less. In the end, inevitably, the engine will stop. When it becomes clear that it will never work, the machine is put under a glass cover near a window in the attic of a museum (Fig. 4, left).

There, by chance, the sun shines through the window (Fig. 4, center), its light falls upon the solar cell (photovoltaic cell) that is a part of the engine. The engine starts working, the heat generated in every step of the operations (Fig. 4, right) lets the glass cover break and so sets the engine free-from now on, it will work "forever," at least as long as the sun keeps shining, and as long as it does not break.

Apart from how the engine works internally, apart from the forces that operate in its interior, there are two noteworthy external circumstances that let the perpetual motion machine work. First, there is the Sun that sends its light to Earth. Second, the heat invariably produced in any real operation in nature and engines, can escape to the environment and from there to outer space. The engine is a mechanism that works in an open flow system that is the surface of our planet.

\section{Agents Representing Forces of Nature}

We tell our students that the animation represents forces of nature as agents- the little "spirits" that animate the perpetual motion machine (Fig. 3, two pictures on the right, and Fig. 4). This form of imaginative rendering parallels our experience 
of agency that emerges from the experience of forces (of nature). We show students that these spirits embody all three main aspects of a forces: intensity (in their bodily expression), quantity (in their size), and power. Their power shows up when they interact in physical elements of the machine. We point out that these elements have moved to the background whereas the spirits have become the figures acting before this new ground (this is an example of the cognitive operation of figure-ground reversal; Fuchs et al. in press, Fuchs et al. forthcoming).

\section{Power and Energy}

Forces are (more or less) powerful, which becomes apparent when agents, as representants of forces, interact. In cognitive science, we speak of agents (the causing element) giving energy to the patient (the receiving, accepting, or suffering element). This is quite similar to how the concept of energy is understood in generalized continuum physics (Paper I: Identifying the Imaginative Structure of Continuum Physics; Paper I: The Gestalt of Direct Manipulation, and Paper I: Fig. 6; for an extended treatment, see Fuchs 2010). So, for instance, if electricity drives a water pump, electricity is the agent, water is the patient, and electricity "hands" water some energy so that water may flow in the opposite "direction" of what it does spontaneously: it is forced to flow uphill.

In Deichmann's animation, energy is represented metaphorically as dust (most easily seen in Fig. 3, second from right, where light "hands" dust to the sleeping/ relaxed agent representing electricity in a photovoltaic cell). In physics, we say that a driving force makes energy available which is then used by one or, usually, two or more caused forces. Typically, there is a single caused process we focus on (water in the case of a water pump), and a second phenomenon we do not bargain for, but which appears invariably in all real processes: the production of heat (the orange serpent in Fig. 4, right).

As students can see in the animation, if the same processes run at different speeds, the rate at which dust (energy) is exchanged in interactions of agents is different: low rate in "low power" interactions, high rate in "high power" interactions; therefore, power is conceptualized as the rates at which energy is either made available or used.

\section{Properties of Energy}

After clarifying dust in Deichmann's animation as representing the concept of energy as it appears in physics and chemistry, we discuss with student teachers the following basic (metaphorical) aspects of this quantity and how it relates to forces of nature:

In interactions of forces of nature, energy is made available by the first (causing, driving) agent and used by the second receiving agent (by the patient). An agent can make energy available only if it is tense. Energy is used by a patient, not used up. 


\section{PROZESSDIAGRAMM WINDRAD MIT LAMPE}

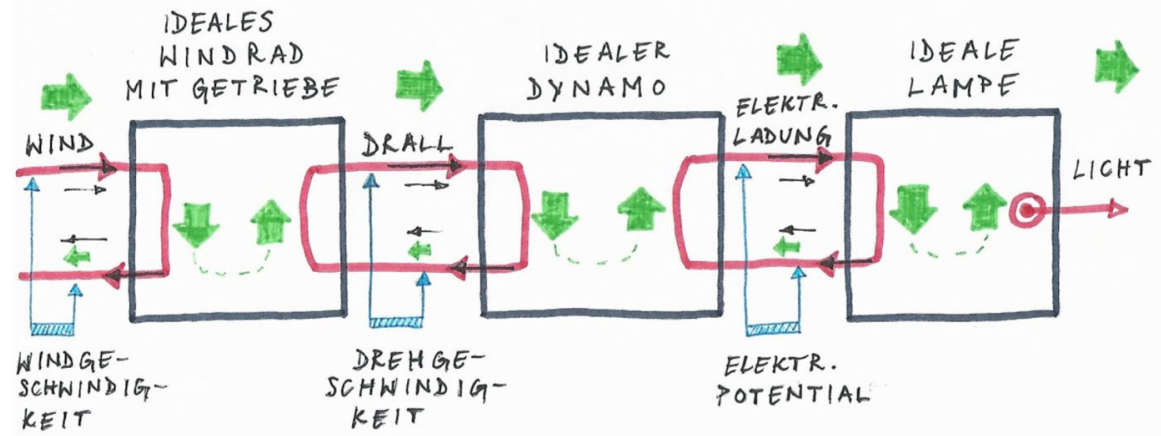

Fig. 5 Simplified process diagram of a windmill-dynamo-lamp assembly (created by a group of students as part of a small lab project in our German language physics course at the Free University of Bolzano at Bressanone, Italy, 2019)

Energy can be transported. Agents carry the energy they have collected from one place of interaction to the next (these places where interactions occur may be called "meeting places"). We call the agents energy carriers.

Energy is the same in all processes, there are no different types of energy. Energy is never converted.

A patient usually "misses" or "loses" some of the energy made available by the agent. Energy that is "missed" by a patient in an interaction is not "lost." It is used by a new patient, namely, heat. (Amount of heat or caloric is produced when energy that was "missed" by a patient during an interaction is used; physicists and engineers say that the energy used during the production of caloric is dissipated.) Energy is not produced nor destroyed (or lost). There is always the same amount of energy in nature. (Physicists say, energy is conserved.)

Even though there is always the same amount of energy in nature, energy can be used only if it has been made available by an agent. An agent can make energy available only if it is tense.

Energy can be stored in materials (together with agents/patients that have carry the energy).

At least some of the properties of the concept of energy listed here clash with how our students and experts alike speak about energy. Even in textbooks, we read that energy is produced and lost, that it is converted from one form to another, or even that motion is transformed into energy or energy is transformed into light or electricity. Interestingly, the talk of "energy conversion" is a tool for avoiding the agents that represent the forces of nature. If we say that "a solar cell converts light into electricity," we (1) assume that light and electricity are energy (rather than metaphorizing them as agents and energy carriers), and (2) by doing so, we cover up what actually matters in physical systems and processes, namely, the existence and properties of the agents our mind introduces as representants of forces of nature. 


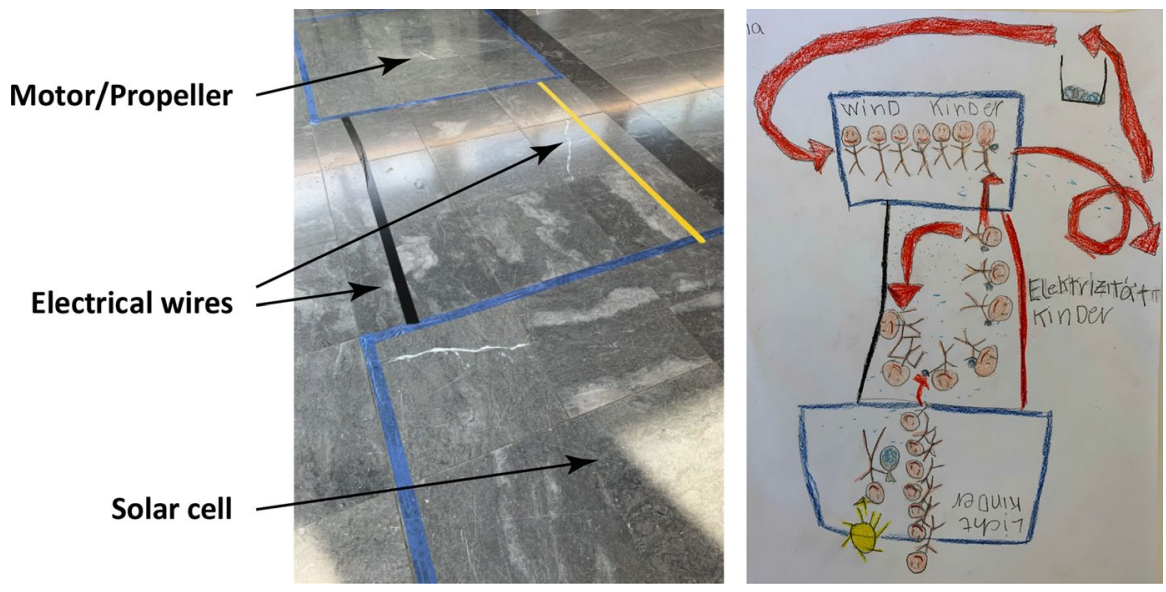

Fig. 6 A primary school class in Switzerland (2nd graders) play forces of nature acting and interacting in a lamp-PV-cell-motor/propeller system. Left: The floor with an outline of solar cell (bottom) and propeller (top) with the paths (cables) for electricity between them. Right: A drawing by a child made after playing the Forces-of-Nature Theater

\section{Process Diagrams}

We teach our students to discuss in group and develop process diagrams (Corni et al. 2019a) for creating visually metaphoric representations of systems and processes (Fig. 5) according to the graphical representation reported in Part I. Potentials are metaphorized as levels. Agents are represented as fluidlike quantities that flow, are produced, drop through a tension, or are pumped. These fluidlike quantities make energy available or use it and transport it. All of this activity takes place in and between what we call couplers-schematic representations of natural or technical entities/devices (a leaf on a tree, an electric water pump...) that have receded to the background, and where forces interact. A couple of more examples of process diagrams are shown in Figs. 6 and 7 of Paper I (Process Diagrams as Visual Metaphors).

\section{Forces-of-Nature Theater}

Deichmann's (2014) Perpetuum Mobile animation has inspired us to create what we call a Forces-of-Nature Theater which we play with our students (Corni et al. 2019b); it has been used successfully before in primary school with children as young as six years (Fig. 6). A combination of the dynamics of systems and processes playing out in the animation and the schematic figures contained in process diagrams presents us with an idea of how to play-act forces of nature. People-children-can act as agents moving on a stage laid out like a chain of couplers with paths between them (Fig. 6, left). The layout of the stage is suggested by a process diagram for the system modeled; examples of process diagrams are found in Fig. 5, 
and in Paper I: Process Diagrams as Visual Metaphors. People acting as forces-ofnature-agents can move on the stage according to the flow of fluidlike quantities, interacting inside the couplers by exchanging something symbolizing energy (Fig. 6, right).

As an example, consider an electric motor driven propeller producing wind. The motor works with electricity that is pumped by light in a solar cell. With a large enough group of pupils in such a Forces-of-Nature Theater, student teachers can imagine assigning roles to fairly large teams that each learn to physically represent the properties of a fluidlike quantity-moving (flowing) along paths and expressing degrees of tension (tense or relaxed). For example, a team of children could be assigned the role of electric charge, i.e. the "electricity kids", and another team could be assigned the role of the Sun's light (the "light kids"). The "electricity kids" line up along the closed path connecting a solar cell and the motor/propeller producing wind (Fig. 6, right). Initially, they can all be relaxed. Then, "light kids" move in one by one. They will have been handed confetti-as an analog of dust/energy-by the "Sun" (maybe played by a teacher), which they now hand to the waiting "electricity kids." An "electricity kid" who has just received some confetti will become tensed and start moving (the entire loop of "electricity kids" will start moving).

The tensed "electricity kids" will eventually hand the confetti they received to "wind kids" waiting in the propeller (the floor space representing the propeller). As they do this, they relax and move back toward the solar cell. Note that in every act of handing over confetti from one type of agent to another, some confetti will invariably fall onto the floor. The lost confetti will be available to "heat kids" who carry them away inside the room.

There are a couple of interesting things some of the agents have to learn: "light kids" are "born" at the surface of the Sun and "die" in the solar cell, "electricity kids" are always there sometimes moving in a circle, and "heat kids" are "born" as they pick up confetti that fell to the floor. In all of this, the persons acting as forces of nature will experience an embodied (physical) logic of what forces of nature can and cannot do, and what happens to energy (confetti) and what does not. Just to mention a couple of points: agents do not "convert" into one another; agents are not energy; energy is always the same as it makes its way through a chain of devices and processes-energy does not change form.

\section{Writing Stories of Forces of Nature}

Story production is performed by students in preparation for the exam and, in a slightly different way, in laboratory activities. We want teacher students to become competent creators and narrators of good stories of forces of nature for children, so we provide them with the basis of narrative theory and practice for primary education.

In the lectures, we introduce the theme by critically question if there is, as Bruner (1990) insists, a dichotomy between narrative understanding and paradigmatic thought or if we should think of a continuum between these two forms of understanding. We encourage our students to reflect on the fact that if forces of nature are 
perceived as powerful agents, we can recruit them as characters acting and suffering in stories. This also suggests that what has been said about the role of narrative in cognition - that (1) children learn to understand people through the stories they hear (Gallagher and Hutto 2008) and (2) hearing or reading stories creates narrative experience that is in many ways analogous to real or physical experience (Caracciolo 2014)—will apply to stories of forces of nature as well.

We teach students the fundamental storytelling rules. For a story to be affective, it should reflect a typical story-schema (Egan 1986). In its simplest structure, a story takes its emotional onset from a tension created by an opposition or polarity (good and bad, happy and sad, discomfort and well-being, etc.), then it tells how the characters act or suffer to solve the tension or mediate between the poles; the story ends when the tension is equilibrated or solved. Students can recruit forces of nature as actual characters and their "adventures" recounted; just as human peculiarities drive typical stories, so do the properties of forces of nature and their interactions (see Fuchs 2013).

It is important for student teachers to realize that children exposed to the metaphors embedded in and receiving meaning through such stories can learn how forces are structured (remember the aspects of quantity, intensity and power we want children to learn about). Hearers of these stories can find out about whether or not fluidlike quantities are conserved, how they accumulate and flow, how they relate to their potentials and potential differences, how they drive other phenomena, i.e., how they interact with other agents, etc. In other words, students try to make children learn to mentally create story-worlds, which become the bases for their scientific models of forces of nature. If we believe that (physical) science is a product of our imagination, it can be taught narratively in stories that use high-quality natural language (Fuchs 2015). In concluding the course, we give students stories of forces of nature (Corni 2013) ${ }^{14,15}$ for analysis in terms of story-schema, character-schema and the concepts they have been exposed to in our course.

Through exposure to stories and story writing activities, student teachers should have become aware that stories of forces of nature mediate between narrative understanding and paradigmatic thought. A curriculum of primary science education becomes a set of great narratives to be told to children with the teachers being narrators and storytellers of this part of human culture.

\section{Toys and Forces of Nature-A Lab Project}

To give the reader a feeling for what can be achieved in a laboratory that is part of our course, we briefly describe activities in one particular lab that lasted for five 4-hour periods. Remember that the division of labor between lectures and labs

\footnotetext{
14 The stories are available in English at the following links: http://www.hansfuchs.org/MATERIALS/Essay1_Modena_2013.pdf. http://www.hansfuchs.org/MATERIALS/Essay2_Modena_2013.pdf.

15 See also The Apple Story (https://fchgo.eu/toolkit-development/) that was produced for the EU Project FCHgo in 2019.
} 
depends upon the concrete curriculum of and infrastructure available at a particular university.

We used the first lab for experiments: Discharging water from a plastic bottle through a straw; equilibration of water levels in two plastic bottle connected by a straw; cooling of hot water in different (sealed) cans; diffusion and osmosis in a piece of cucumber into which a hole was bored and filled with salt. After performing and documenting the experiments and observations in teams, students were asked to produce their first narrative explanations using forces-of-nature conceptualizations.

The second lab was devoted to finding and analyzing linguistic expressions for a force of nature (such as wind, light, fire, heat...) according to (image) schematic and metaphoric structures. Lab 3 was used to analyze a story of forces of nature presented to the students; the analysis concerned story structure and metaphoric elements.

Then we moved on to a small project for the last two lab sessions. Students were given a toy (we had examples of a hand-cranked dynamo torch; a windmilldynamo-light assembly; a solar-electricity-car; and a solar-hydrogen-car). The teams of students assembled the toys, operated them under various conditions, described assembly, operation, and function of the toys using narrative explanations and process diagrams in a form appropriate for adults. Then they challenged themselves in planning how to set up a Forces-of-Nature Theater representing the functioning of their toy for a class of primary school pupils. Finally, students created a story of forces of nature for children inspired by the toy. All the pieces of their project were documented in a short report.

\section{Explicit System Dynamics Modeling and Numerical Simulation}

Apart from theoretical background material of physical science (see Paper I: section on Identifying the Imaginative Structure of Continuum Physics), there is one more theme treated in our course that is meant to strengthen our students' understanding of science and its practice independent of questions whether or not the subject is amenable to teaching in primary school. This is the field of system dynamics modeling and simulation (Corni et al. 2019a). By introducing our students to this methodology we pursue a couple of ulterior motives: (1) we want to discuss epistemology by showing how knowledge is produced in physical science by applying a modeling-based scientific methodology, and (2) motivate our students for issues in the field of complex dynamical systems which play such an important role in human interactions with nature and society (for a discussion of narrativity in complex systems, see Fuchs et al. (forthcoming)).

Let us stress, however, that there are examples of the application of system dynamics modeling in primary school, and that this constitutes a field of ongoing research (see, for instance, Zuckerman 2004, and references therein). An important source of examples can be found in the Roadmaps produced for the System Dynamics in Education Project at MIT in Cambridge, MA. Note that our 
examples of embodied simulations of the balancing amount of fluidlike quantities and of the discharging (and filling) of a tank (see above in Embodied simulations and Fig. 2) constitute applications of system dynamics modeling and simulation relying on our bodies and paper and pencil rather than computers.

\section{Background}

About 30 years ago, advances in software engineering opened up an entirely new world to the lay person: the creation and simulation of dynamical models with the help of graphical user interfaces (Paper I: Metaphors, Narrative, and Formal Dynamical Models; see also Fuchs 2002). These graphical user interfaces make a few of the fundamental schematic forms available for metaphoric projection onto conceptualizations of forces of nature. To demonstrate how this works for our students, let us construct a simple model of discharging of a water tank in the software tool Insight Maker (Fig. 7). ${ }^{16}$

In Paper I, we have described how imagination helps us create models. ${ }^{17}$ Here, we want to concentrate mostly upon the mechanics of modeling and simulation. Any modeling activity presupposes some experience-observation, experimentation, data analysis, telling of what has happened, etc.- - with a concrete system or mechanism and an at least rough idea of what question(s) one would like to answer with the help of the model and its simulation.

\section{A Word-Model}

In our example, a quick word model might look as follows. (1) At any given moment, there is a certain amount of water in the tank (measured in terms of volume); maybe,

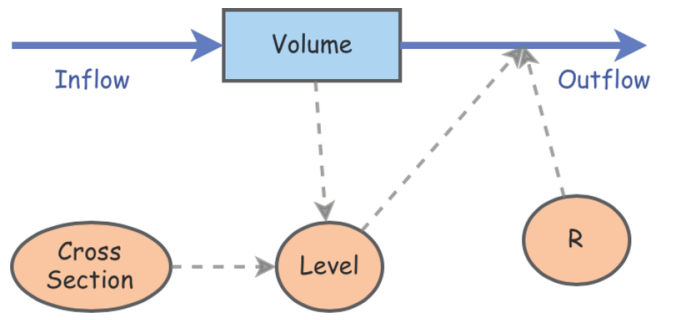
(a) d/dt (Volume) $=$ Inflow - Outflow
(b) Init_Volume $=40$
(c) Inflow $=4$
(d) Outflow $=$ Level / R
(e) Level = Volume / Cross_Section
(f) Cross_Section $=2$
(g) $\mathrm{R}=2$

Fig. 7 Left: Graphical representation of ideas making up a model of draining of a tank through a horizontal pipe at the bottom. Right: Equations making up such a model

\footnotetext{
16 Insight Maker (http://www.insightmaker.com) is just one of a handful of dynamical modeling programs that sport graphical interfaces. It is a free browser-based program running online. Its tools (especially the numerical methods) are quite limited but sufficient for our purpose. A tool that has a simpler and more stable graphical interface is Stella (iseesystems.com). Berkeley Madonna (berkeley-madonna. myshopify.com) makes better numerical methods available for heavier scientific work.

17 We tell stories of processes undergone by the forces of nature in a particular system under specific circumstances. Such stories let story-worlds emerge in our mind. Story-worlds contain ideas that are used in the construction of formal models.
} 


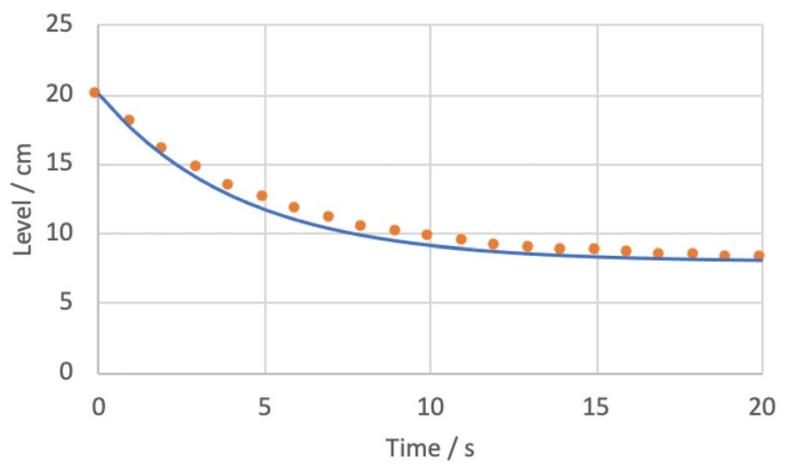

Fig. 8 Simulation of the model shown in Fig. 5 (solid line) compared to an imported set of data (points)

at the starting point, there is already some in the tank. (2) The amount of water can only change as a result of inflow and/or outflow of water. (3) The inflow is held constant. (4) The more water there is in the tank, the higher its level, and therefore the pressure of the water, will be. (5) The outflow must depend upon this pressure: the higher the pressure, the stronger the flow.

\section{Constructing the Model}

This list that can be presented as a little narrative, suggests structure and logic of the model. (1) We need to represent the amount of water as a variable that can accumulate (the rectangle in the model diagram in Fig. 7), and we give it the name of the quantity we are going to do the accounting for: Volume. The rectangle (called stock or reservoir) is initialized with the initial amount of water in the tank (equation (b) on the right in Fig. 7). (2) The processes this system undergoes are represented by inflow(s) and outflow(s) - therefore, we need to connect flow arrows (an inflow and an outflow) to the reservoir and give them the names Inflow and Outflow. Upon completing the drawing of the two flows connected to the stock, the software creates equation (a), which is the mathematical equivalent of the law of balance of volume of liquid in our present case. (3) The inflow is given a certain fixed value (equation (c)). (4) In order to obtain the pressure of the water in the tank-which will be needed to calculate the outflow-we introduce a variable (called Level). Since the level of water in the tank depends upon the cross section of the tank as well, we introduce a constant called Cross Section. Then, Volume and Cross Section are connected by "Links" to Level. Now, we have to write an equation: For a straightwalled tank, we have equation (e) that expresses the concrete capacitive relation. (5) Finally, we need to express an idea regarding how the outflow might depend upon pressure; if the flow is simple, we can use equation (d): the flow is proportional to pressure, and inversely proportional to a constitutive factor that measures how strongly the flow is resisted. This factor is usually called flow resistance, which we have introduced as a constant factor $R$ in the model diagram. 


\section{Simulating the Model}

When we give Cross Section and R concrete values (equations (f) and (g)), we are done, and we can attempt to simulate the model by means of the software. This normally involves setting some simulation parameters first, such as initial and final time for the simulation time span. Also, we need to specify the numerical method the software is supposed to use when solving the set of equations in Fig. 7 (if the software allows us this choice). Simulation results are normally presented in some output graphs. In the example presented here, the simulated level looks like the curve of red dots in Fig. 2. In Fig. 8, we show a simulation result plus an imported dataset (the data is fake: it was produced by hand to show what can be done with actual experimental datasets). In order to get simulation and dataset to fit as well as possible, parameters (Cross Section, $R$, Inflow, and/or initial value of Volume) need to be changed.

\section{Discussion}

Our students can quite easily learn to create models of the type introduced above. It takes some time, effort, and patience, but it works, and after a few tries even more complicated examples can be created. We have been able to ascertain that dynamical modeling is worth the while even (or maybe especially) in a course that treats physical science mostly qualitatively. Our students express satisfaction and demonstrate improved conceptual understanding of physical systems and dynamical phenomena.

System dynamics diagrams such as the one in Fig. 7 are often called maps. As mapping becomes an educational theme during the growth of tools of literacy (see Egan 1997, on the romantic phase of understanding related to development of literacy), it seems reasonable to introduce children in primary school to mapping representations of mental models of how certain processes and system work. Again, note how graphical mapping of a model as in Fig. 7 can go hand in hand with the example of embodied simulation presented above (Embodied simulation and Fig. 2).

\section{Understanding Practices of Modern Science}

As we have pointed out above, with system dynamics modeling we pursue goals that go beyond preparing our students most directly for how they might be able to teach science in kindergarten and primary school. Creating dynamical models in general, and of forces of nature in action in natural and technical systems, has become a fundamentally important aspect of the practices of modern science. This practice has taught us much about the epistemology of science in general and of physics in particular, and it is an indispensable tool-again, both epistemologically and practically - in our dealings with complexity (see Fuchs et al. (forthcoming) for a more detailed discussion of these issues from the vantage point of a narrative approach to science). Of all the meta-issues of science education for future teachers, dynamical modeling and simulation might be one of the most relevant and interesting themes in our course. 


\section{Steps Towards an Evaluation of the Course}

The central aim of our course is to empower our students to become confident and competent creators and narrators of good stories of forces of nature for children. Naturally, there are many more goals we pursue with our teaching, such as some knowledge of theory and practice of figurative language, a facility with of aspects of cognitive narratology, and understanding of elements of the science of forces of nature (largely in qualitative form, including diagrammatic techniques, and experimenting with and modeling of some simple dynamical physical systems). In one way or another, however, they are all subsidiary to this one central goal.

Some qualitative and quantitative results of student feedback (including results from exams) have been presented at conferences (GIREP, ESERA, WCPE). Learning of the science covered in the course has been assessed (Corni and Dozza in press; Landini et al. 2019; Corni et al. 2019b, 2014a). Students' abilities for creating and analyzing stories of forces of nature have been evaluated (Corni et al. 2014a, b), and we have collected feedback concerning students' inclination towards physics and perceived personal skills (Corni et al. 2014a).

Here we will present new results, relevant for the specific aim of this paper. In order to have information about the effectiveness of the course, we have solicited answers to a few questions from former students who have been teaching in kindergarten and primary school for at least a few years. We also have quantitative results from a general end-of-course survey. After briefly reporting these results, we will discuss, in some depth, a case study of research done by a student for her master thesis that can serve as an indication of what students learn from an imaginative approach to PPSE.

\section{A Recent Survey Among Former Graduates}

At the beginning of 2020, 24 former student teachers answered a questionnaire sent out to 44 of course participants who had done work beyond lectures and labs. We briefly synthesize answers of the 14 students who took the course most recently.

How do you feel about science and science teaching (weak, secure, autonomous, ...)? The great majority of the teachers (86\%) feel (mostly) confident and/or autonomous in teaching science. Most of them are aware of their need for further training and study.

To what extent and in what way do you feel helped by the approach taken in our PPSE course? Almost all the teachers declare that they adopt the approach of the course in their own teaching. In some cases, they explicitly express great satisfaction and that the course shapes their teaching. The course opens up a fresh and effective way of teaching science including simple and concrete themes and tools. In particular, the course gives the teachers a methodology for observing and understanding their pupils' learning. The use of stories is mentioned by the $36 \%$ of the teachers.

Which elements of the course have shaped your teaching-not just of science-in the most profound ways? The most frequent course features teachers have become aware of as important for their teaching are the use of stories, metaphors and 
Table 4 Primary (pre-scientific) and formal lists of forces of nature

\begin{tabular}{lllll}
\hline Question & $\begin{array}{l}\text { Disagree } \\
\text { completely } \\
(\%)\end{array}$ & $\begin{array}{l}\text { Disagree } \\
\text { mostly } \\
(\%)\end{array}$ & $\begin{array}{l}\text { Agree } \\
\text { mostly } \\
(\%)\end{array}$ & $\begin{array}{l}\text { Agree } \\
\text { completely } \\
(\%)\end{array}$ \\
\hline $\begin{array}{l}\text { Did you have sufficient prior knowledge to under- } \\
\text { stand the subjects? }\end{array}$ & 7 & 21 & 46 & 26 \\
$\begin{array}{l}\text { Does the instructor stimulate/motivate interest in the } \\
\text { discipline? }\end{array}$ & 0 & 5 & 33 & 62 \\
$\begin{array}{l}\text { Does the instructor explain the topics clearly? } \\
\begin{array}{l}\text { Are you interested in the subjects of the course? } \\
\text { Overall, are you satisfied with the way the course has } \\
\text { been done? }\end{array}\end{array}$ & 1 & 9 & 43 & 47 \\
\hline
\end{tabular}

analogies. $36 \%$ of respondents say that these linguistic tools have become central elements of their overall approach to teaching. They frequently use experimental work in teams where the syllabus asks for frontal lessons, and they note that they have learned to be able to listen their pupils. Again, $36 \%$ of the teachers say that the PPSE approach provides them with an integrating point of view for the various disciplines and activities in their teaching.

\section{An End-of-course Survey}

A significant source of information about reactions of our students to the course comes from the end-of-course survey which has been taken by a total of 386 students. It is composed of general non-technical questions. The items most interesting for our purpose here are summarized in Table 4.

Despite their weak academic background in the sciences, most of the students feel that they can follow the course as it is structured and the topics as they are presented (only $7 \%$ say that it is definitely too difficult). The students are interested in the discipline ( $83 \%$ positive, $2 \%$ definitely negative) and have been motivated for the subject by the course instructor (95\% positive or fairly positive, no negative). Finally, the students say that they are generally satisfied with how the course has been structured and implemented (90\% positive or fairly positive, $1 \%$ negative).

\section{A Student's Research and Master Thesis in PPSE}

Research and a master thesis are part of the Master-Degree in Primary Education at Italian universities. Since we have adopted the imaginative approach to primary physical science education, more and more students have signed up for doing their thesis in physical science (numbers have gone from close to zero to $15 \%$ to $25 \%$ per class).

Students' research projects usually revolve around a teaching apprenticeship at a kindergarten or primary school during the last two years of the 5-year curriculum. 

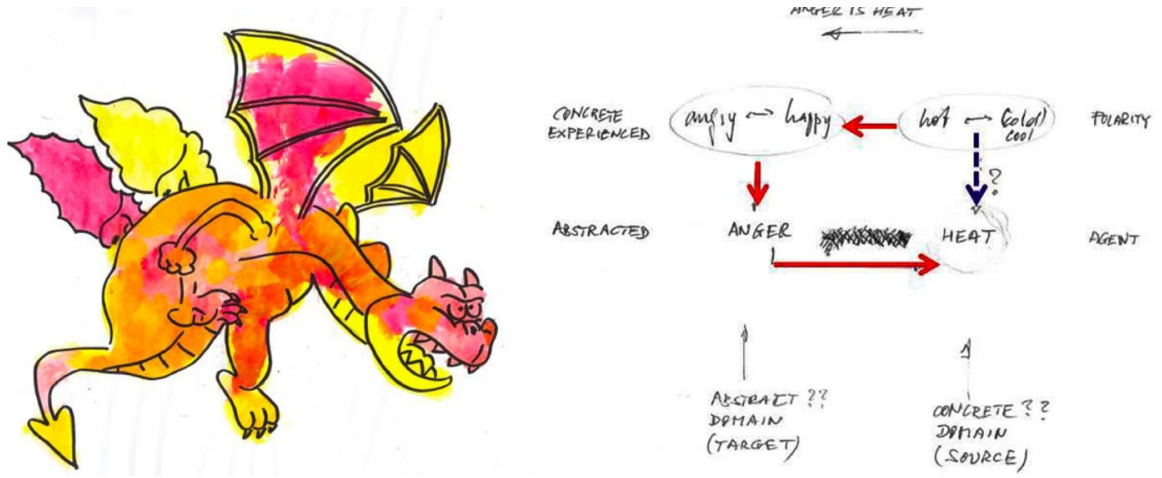

Fig. 9 Angry Spike (left), and conceptual design of analogical relation between ANGER and HEAT (right); Beccari (2016)

Students work under the supervision of both an academic and a school tutor in a classroom for 100 to $150 \mathrm{~h}$.

In the following, we shall report on the research and thesis work of a student who chose to investigate a theme related to heat for 5-year old kindergarten students. The results were presented by the student herself at an international conference on innovation in science education in primary school and kindergarten held at the University of Modena and Reggio Emilia (Beccari 2016).

\section{A Story of Anger and Heat}

The student teacher's idea was to introduce the children to heat as a force of nature by speaking about a psychological force they are well aware of-namely, anger. She designed, wrote, and illustrated a story of a dragon about anger and heat (Fig. 9, left) on the basis of metaphors children used for anger during individual interviews with them. Here is the English translation of the story:

A long time ago there was a small dragon called Spike. He lived with his father and mother on top of a high mountain. He spent most of his time in the air flying, and he observed the world from above. Spike was a happy dragon [illustration].

But he had not yet met Anger and Heat. Anger and Heat were two small spirits, almost identical, always together and always ready to quarrel. They spent their time getting into and out of things and people. The difference was that Anger was angry and Heat was warm. Anger was red while Heat was yellow [illustration].

One summer afternoon, Spike was happily flying in the sky, when he saw some children playing in a pool. He liked water too and thought this might be a nice opportunity to play with the children. But he remembered that his mother and father always warned him to stay away from children because they were afraid of dragons [illustration]. 
Then Anger and Heat suddenly entered his body. He didn't know this at first, but he soon felt it. And very clearly! Spike immediately felt angry and hot. His face got very angry and frightful, and his mouth began spitting smoke. Spike looked at himself in a cloud ... he had angry eyes, angry mouth, angry eyebrows, angry cheeks. His cheeks also felt very hot. Indeed, Spike's whole body was hot. Anger and Heat were in Spike's head. Spike was angry, angry, very angry. He was also hot, hot, very hot. And he felt sick because he couldn't control all that rage and all that heat inside his body. He absolutely wanted to drive the small phantoms out of his body because then he would have felt well [illustration].

While flying and flapping the wings and spitting smoke, he approached the swimming pool with the children playing. The children were so happy, and he really wanted to play with them. Suddenly, he lost his balance and fell into the pool, just next to the children [illustration].

But the children were brave and were not afraid of dragons. They made friends with Spike and wanted to play with him. Spike was amazed and was very happy to play with them and felt their love. Anger and Heat, meanwhile, had left Spike's body and had gone off to quarrel somewhere else. Spike was calm again and played with the kids [illustration]. (Original in Italian; Beccari 2016)

The main metaphors embedded in the story are ANGER/HEAT IS A FLUIDLIKE SUBSTANCE, THE BODY IS A CONTAINER FOR ANGER/HEAT, and ANGER/HEAT IS A POWERFUL AGENT. The assumption of the student's thesis was that since heat and anger are presented together to children, metaphors for anger should apply analogously to heat (see Fig. 9 right). Example expressions for the three metaphors are "Then, Anger and Heat suddenly entered his body;" "Anger and Heat, meanwhile, had left Spike's body;" "And he felt sick because he couldn't control all that rage and all that heat inside his body."

\section{Rationale for the Structure of the Story}

We all know the feeling of warmth or heat accompanying the occurrence of anger. Metaphoric expressions such as "he blew his top" testify to how our mind makes use of its metaphoric power by creating figurative structures. Such structures have been investigated intensively in cognitive linguistics. One way the results are commonly summarized is to postulate the existence of a conceptual metaphor ANGER IS A HEATED FLUID (Koevecses 1986; Lakoff and Kövecses 1987).

For our purpose, it is advantageous to consider anger an emotional force. Indeed, our analysis of the structure of FORCE applies to anger just as it does to other forces. If we go back to our model of blending and analogy where the same metaphors applied to different forces make these forces similar to our mind (Paper I: Fig. 2), we see that anger and heat can be considered analogous to some degree. The reason for using a story involving the joint action of anger and heat can now be formulated as follows: children hearing the story are supposed to learn to compare experiences of heat and anger in order to learn from one for their understanding of the other. We 
might conjecture that knowledge of anger is closer to a small child who then can transfer such understanding to the subject of thermal phenomena. But it does not really matter which of the two is dominant in a child's mind at the outset; we hope to foster increased understanding of and strengthened linguistic ability in describing their experiences of both anger and heat.

\section{Using the Story}

During the project, the student teacher worked with two groups of children, an experimental group and a control group. In the case of the experimental group, the use of the story was accompanied by a series of activities to help children grasp the behavior of the two forces (of nature and of our psyche) such as discussions about personal experiences; dramatizing the plot of the story; and experiencing heating of water by immersion of hot stones, drawing of pictures of the experience in temporal sequence, and discussion of what happened during the process. The control group did the activities relating to the thermal phenomena but was not exposed to the story.

The results of the project were twofold. For one, there was the effect upon the children; secondly, there was a demonstration of professional competence by the student teacher. As far as the children were concerned, those in the experimental group developed a sense of heat as an agent-they demonstrated this verbally, in their drawings, and in their play.

In the control group, this specific form of development of imagination and fantasy did not take place. Children never mention heat or, more generally, a fluidlike substance responsible for thermal processes, and would only say that the water became hot because the stones were hot and that the stones became cold because the water was cold: water and stones changed their qualities in response to each other; there was no indication of equilibrium reached in the end.

\section{Summary}

For the purpose of the present study-i.e., teacher education-we are interested in how well the student teacher learned to work with elements of PPSE. The student was able to apply what she had learned about psychology, physics, metaphor, and narrative, both during the design phase of the story when she investigated children's conceptions of anger, and in her research and analysis of conceptualizations children demonstrated in various ways during the natural science activities. The study demonstrates the ability of a young teacher to apply metaphor research and narratology to science teaching. In other words, it demonstrates how the student teacher lets studies in the humanities interact with those in primary science in a practical situation.

\section{Summary and Conclusion}

Let us conclude the paper by briefly summarizing aspects of both the philosophy and the design of the course we believe to be of particular value. 


\section{Experience and Embodiment}

We base the course upon a philosophical and cognitive model of embodied experience. The term experience is taken in Dewey's sense as the result of feedback in action-perception loops, occurring between an organism and its physical, social, psychological, and cultural-linguistic environments. This has suggested to us a pedagogy for primary physical science education that combines direct physical and narrative experience.

\section{Elements of Primary Conceptualization of Experience}

We make use of the primary embodied conceptualizations of nature available to us in figurative (metaphoric and narrative) thought and language that children have access to as well. This assures our students of their ability to independently make use of tools of imagination and makes them more positively inclined toward the sciences.

\section{Integration and Continuity}

The course is integrated at several different levels. We strive for continuity between lectures and laboratory activities, and practice through apprenticeship in school (including thesis work for those student teachers who want to complement their courses with research in physical science education). Second, what is taught, and how it is being taught, often applies directly to pedagogy for young learners. This allows in-service teachers to profit from training courses that make use of PPSE. Third, we integrate important elements of the humanities taught in the masterdegree program with our approach to physical science. Applying metaphor and narrative theory, and a theory of cognitive development along cultural stages, to our model of experience and conceptualization of nature serves as a powerful bridge with pedagogy, linguistics, psychology, sociology, and science.

\section{Natural Language and Non-linguistic Forms of Expression}

As our students learn about physical phenomena, the course develops their facility with language that preserves the images created in our mind by experience of forces of nature. Having this ability is important for our students in at least two respects: being able to speak "naturally" about nature and knowing how they can use a child's language to probe his or her understanding. Our emphasis on figurative forms of natural language use (metaphor, analogy, narrative) is meant to train our students in this field.

Moreover, several different forms of expression (gestural, embodied simulations and Forces-of-Nature Theater, diagrammatic, and iconic) are engaged when we are 
dealing with scientific subjects. This ties in well with the temporal development of the cognitive tools available to children. Only elementary mathematics is needed in this approach, even in the case of system dynamic modelling.

\section{Practical, Student-Centered Teaching and Assessment}

Our students are assessed in a manner that coheres with the course philosophy. They have to show their creativity in designing direct physical experience of forces of nature for their young students, and their ability to put communication about such experience in narrative form by writing stories of forces of nature. Such stories are required to demonstrate our students' mastery of generic aspects of forces of nature (experience of intensity, extension, and power) and the application of concepts to concrete cases where knowledge of constitutive relations for storage, flow, and production/destruction and energy relations are needed. In this way, our students can demonstrate how they combine conceptual knowledge with pedagogical knowledge.

Acknowledgements This work was developed within the PPSE project n. 3801 (Primary Physical Science Education. Courses and materials for teacher education based upon an imaginative - metaphoric and narrative - approach to the experience of Forces of Nature. Principal Investigator: F. Corni, 1/9/201931/7/2021) funded by the Free University of Bozen-Bolzano.

Funding Open access funding provided by Libera Università di Bolzano within the CRUI-CARE Agreement. Funding was provided by Libera Università di Bolzano (BW2809 StartUp Project).

Open Access This article is licensed under a Creative Commons Attribution 4.0 International License, which permits use, sharing, adaptation, distribution and reproduction in any medium or format, as long as you give appropriate credit to the original author(s) and the source, provide a link to the Creative Commons licence, and indicate if changes were made. The images or other third party material in this article are included in the article's Creative Commons licence, unless indicated otherwise in a credit line to the material. If material is not included in the article's Creative Commons licence and your intended use is not permitted by statutory regulation or exceeds the permitted use, you will need to obtain permission directly from the copyright holder. To view a copy of this licence, visit http://creativecommons.org/licen ses/by/4.0/.

\section{References}

Beccari, G. (2016). C'era una volta Rabbia, c'era una volta Calore. Basi emotive del pensiero razionale. Master Thesis, Dipartimento di Educazione e Scienze Umane. University of Modena and Reggio Emilia, Italy.

Bruner, J. S. (1990). Acts of meaning. Cambridge, MA: Harvard University Press.

Caracciolo, M. (2014). The experientiality of narrative. An enactivist approach. Berlin: Mouton de Gruyter.

Close, H. G., \& Scherr, R. E. (2015). Enacting Conceptual Metaphor through Blending: Learning activities embodying the substance metaphor for energy. International Journal of Science Education, 37(5-6), 839-866.

Corni, F. (Ed.). (2013). Le scienze nella prima educazione. Un approccio narrativo a un curricolo interdisciplinare. Trento IT: Erickson.

Corni, F. (2014). Stories in physics education. In S. Burra, M. Michelini, \& L. Santi (Eds.), Frontiers of Fundamental Physics and Physics Education Research (Springer Proceedings in Physics) (pp. 385-396). Springer International Publishing. 
Corni, F., \& Dozza, L. (in press). Max's Worlds: an innovative project for K-6 science education. Journal of Physics: Conference Series.

Corni, F., \& Fuchs, H. U. (2020). Primary physical science for student teachers at kindergarten and primary school levels: Part I-foundations of an imaginative approach to physical science. Interchange, 51, 315-343. https://doi.org/10.1007/s10780-019-09382-0.

Corni, F., Fuchs, H. U., Giliberti, E., \& Mariani, C. (2014). Primary School Teachers: Becoming Aware of the Relevance of their own Scientific Knowledge. In M. F. Taşar (Ed.), Proceedings of The World Conference on Physics Education 2012 (pp. 1063-1072). Pegem Akademi.

Corni, F., Giliberti, E., \& Fuchs, H. U. (2014). Student Teachers Writing Science Stories: a Case Study. In C. P. Constantinou, N. Papadouris, \& A. Hadjigeorgiou (Eds.), ESERA 2013 - Science Education Research for Evidence-based Teaching and Coherence in Learning (pp. 2494-2505).

Corni, F., Fuchs, H. U., \& Savino, G. (2018). An industrial educational laboratory at Ducati foundation: Narrative approaches to mechanics based upon continuum physics. International Journal of Science Education, 40(3), 243-267.

Corni, F., Fuchs, H. U., Landini, A., \& Giliberti, E. (2019). Visual and gestural metaphors for introducing energy to student teachers of primary school and kindergarten levels. Journal of Physics: Conference Series, 1287, 012043. https://doi.org/10.1088/1742-6596/1287/1/012043.

Corni, F., Fuchs, H. U., \& Dumont, E. (2019). Conceptual metaphor in physics education: roots of analogy, visual metaphors, and a primary physics course for student teachers. Journal of Physics: Conference Series, 1286, 012059. https://doi.org/10.1088/1742-6596/1286/1/012059

Deichmann, M. (2014). Im übertragenen Sinne. Metaphern und Bildvergleiche in der Wissernschaft. Bachelor Thesis, Zürcher Hochschule der Künste, Zurich. Animation available at: http://vimeo .com/98311515

Dewey, J. (1925). Nature and Experience. In J. A. Boydston (Ed.), The later works (1925-1953, Vol.1). Carbondale, IL: Southern Illinois University Press.

Di Paolo, E. A., Cuffari, E. C., \& De Jaegher, H. (2018). Linguistic bodies. The continuity between life and language. Cambridge, MA: MIT Press.

Egan, K. (1986). Teaching as story telling. Chicago, Ill: The University of Chicago Press.

Egan, K. (1988). Primary understanding. Education in early childhood. New York: Routledge.

Egan, K. (1997). The educated mind. How cognitive tools shape our understanding. Chicago: The University of Chicago Press.

Egan, K. (2005). An imaginative approach to teaching. San Francisco, CA: Jossey-Bass.

English version: Force Dynamic Gestalt, Metaphor, and Scientific Thought. Retrieved from www.hansf uchs.org/LITERATURE/Literature.html.

English version: From mythic thought to an understanding of nature. Retrieved from www.hansfuchs.org/ MATERIALS/Mythic_Thought_and_Science.pdf.

English version: Meaning in Nature-From Schematic to Narrative Structures of Science. Retrieved from http://www.hansfuchs.org/LITERATURE/Literature.html.

Fuchs, H. U. (2002). Modeling of Uniform Dynamical Systems. Zurich: Orell Füssli. Available electronically at http://www.hansfuchs.org/BOOKS/Books/MUDS.html.

Fuchs, H. U. (2010). The Dynamics of Heat. Second Edition. Graduate Texts in Physics. Springer, New York. (First Edition: Springer, New York, 1996.)

Fuchs, H. U. (2011). Force Dynamic Gestalt, metafora e pensiero scientifico. In F. Corni (Ed.), Atti del Convegno "Innovazione nella didattica delle scienze nella scuola primaria: al crocevia fra discipline scientifiche e umanistiche”, Modena IT: Artestampa.

Fuchs, H. U. (2013). Il significato in natura. In F. Corni (Ed.) Le scienze nella prima educazione. Un approccio narrativo a un curricolo interdisciplinare. Trento IT: Erickson.

Fuchs, H. U. (2014). Dal pensiero mitico alla conoscenza della natura. In F. Corni \& T. Altiero (Eds.), Innovazione nella didattica delle scienze nella scuola primaria e dell'infanzia: Al crocevia fra discipline scientifiche e umanistiche (pp. 9-34). Mantova IT: Universitas Studiorum.

Fuchs, H. U. (2015). From Stories to Scientific Models and Back: Narrative framing in modern macroscopic physics. International Journal of Science Education, 37(5-6), 934-957.

Fuchs, H. U., \& Cervi, M. (2015). Wind or Air? A dialogue about forces of nature, emotion, and good stories. In F. Corni \& T. Altiero (Eds.), Innovazione Nella Didattica Delle Scienze Nella Scuola Primaria e Dell'Infanzia: Al Crocevia Fra Discipline Scientifiche e Umanistiche (pp. 87-108). Mantova IT: Universitas Studiorum.

Fuchs, R., \& Fuchs,, H. U. (2020). The Apple Story. A story of food and natures fuels. https://fchgo.eu/ toolkit-development. Retrieved in May 2020. 
Fuchs, H. U., Dumont, E., Corni, F. (forthcoming). Narrativity in complex systems. In A. Zeyer, \& R. Kyburz-Graber (Eds.), Science|Environment|Health. Towards a renewed pedagogy for science education. 2nd edition. Dordrecht: Springer.

Fuchs, H. U., Dumont, E., Corni, F. (in press). The power of forces of nature-How narrative introduces us to the notion of energy. Invited paper at the conference Innovazione Nella Didattica Delle Scienze Nella Scuola Primaria e Dell'Infanzia: Al Crocevia Fra Discipline Scientifiche e Umanistiche. Reggio Emilia, 1-2/2/2019.

Gallagher, S., \& Hutto, D. (2008). Understanding others through primary interaction and narrative practice. In J. Zlatev, T. Racine, C. Sinha, \& E. Itkonen (Eds.), The shared mind: Perspectives on intersubjectivity. Amsterdam: John Benjamins.

Gallagher, S., \& Zahavi, D. (2012). Phenomenological mind (2nd ed.). New York, NY: Routledge.

Geeraerts, D., \& Cuyckens, H. (2010). The Oxford Handbook of cognitive linguistics. Oxford: Oxford University Press.

Hampe, B. (2005). From perception to meaning. Image schemas in cognitive linguistics. Berlin: Mouton de Gruyter.

Hutto, D. D., \& Myin, E. (2017). Radicalizing enactivism. Basic minds without content. Cambridge, MA: MIT Press.

Johnson, M. (1987). The body in the mind. Chicago, IL: University of Chicago Press.

Johnson, M. (2007). The meaning of the body. aesthetics of human understanding. Chicago Ill: The University of Chicago Press.

Jou, D., Casas-Vazquez, J., \& Lebon, G. (1996). Extended irreversible thermodynamics (2nd ed.). Berlin: Springer.

Koevecses, Z. (1986). Metaphors of anger, pride and love: A lexical approach to the structure of concepts. Amsterdam: John Benjamins Publishing Company.

Lakoff, G., \& Johnson, M. (1980). Metaphors we live by. Chicago, IL: University of Chicago Press.

Lakoff, G., \& Johnson, M. (1999). Philosophy in the flesh. New York: Basic Books.

Lakoff, G., \& Kövecses, Z. (1987). The cognitive model of anger inherent in American English. In D. Holland \& N. Quinn (Eds.), Cultural models in language and thought (pp. 195-221). Cambridge: Cambridge University Press.

Landini, A., Giliberti, E., \& Corni, F. (2019). The Role of Playing in the Representation of the Concept of Energy: A Lab Experience for Future Primary School Teachers. In E. M. Kampen \& P. van Kampen (Eds.), Concepts, Strategies and Models to Enhance Physics Teaching and Learning (pp. 125-137). New York: Springer. https://doi.org/10.1007/978-3-030-18137-6_11.

Leavitt, R. M. (2011). Reading a dictionary. How Passamaquoddy language translates concepts of physical and social space. In Swann B. (Ed.), Born in the blood. On Native American Translation. Lincoln, NE: University of Nebraska Press.

Müller, I. (1985). Thermodynamics. Boston: Pitman.

Talmy, L. (2000). Toward a cognitive semantics (Vol. I and II). Cambridge, MA: MIT Press.

Truesdell, C. A., \& Noll, W. (1965). The non-linear field theories of mechanics. In S. Flügge (Ed.), Encyclopedia of physics (Vol. III/3). Berlin: Springer.

Truesdell, C. A., \& Toupin, R. A. (1960). The classical field theories. In S. Flügge (Ed.), Encyclopedia of physics (Vol. III/1). Berlin: Springer.

Varela, F. J., Thompson, E., \& Rosch, E. (1991). The Embodied Mind. Cambridge MA: MIT Press.

Zuckerman O. (2004): System blocks: Learning about systems concepts through hands-on modeling and simulation. MA Thesis, MIT, Cambridge, MA.

Publisher's Note Springer Nature remains neutral with regard to jurisdictional claims in published maps and institutional affiliations. 